\title{
The basic foundations of capoeira' learning: preliminary evaluation of a formative program
}

\author{
Nelson BARROS1, Marco BRANC01,2,3,4 (D) \& David CATELA ${ }^{* 1,2,5}$ (D) \\ ${ }^{1}$ Sport Sciences School of Rio Maior, Polytechnic Institute of Santarém, Rio Maior (Portugal) \\ ${ }^{2}$ Research Unit of Polytechnic Institute of Santarém (UIIPS) (Portugal) \\ ${ }^{3}$ Biomechanics and Functional Morphology Laboratory, Interdisciplinary Centre for the Study of \\ Human Performance-University of Lisbon (CIPER-UL) (Portugal) \\ ${ }^{4}$ International Martial Arts and Combat Sports Scientific Society (IMACSSS) (Poland) \\ ${ }^{5}$ Life Quality Research Centre - CIEQV (Portugal)
}

Received: 28/12/2018; Accepted: 21/05/2019; Published: 23/05/2019.

\begin{abstract}
Capoeira is a simulated duel supported by the rhythmic of instrumentalists, with traditional musical instruments; evolving a constant synchrony with the other capoeirista. Nowadays, capoeira is passed on by traditional processes, according to the past experience and personal interpretations of the Mestre de capoeira (capoeira master/coach). The purpose of this pilot study was to present a preliminary evaluation of a program for learning the basic techniques, for capoeira teaching agents, respecting the cultural and historical values of capoeira' identity; applied to 15 first-grade school children $\left(M_{\text {age }}=8.0 \pm 1.2\right.$ years old), belonging to a non-governmental organization, with integrative social roles, and to a national sports club, all capoeira beginners; throughout 30 sessions ( 90 minutes each), over three months. Results revealed that a significant improvement occurred in the quality of execution of all the twelve selected capoeira techniques, with no significant differences between genders and institutional origin, sustaining the potential cultural and social affordances of capoeira. The practice in dupla (dyad), in the fundamental ginga ability, provided synchronization among children, from the first moment, in tune with one of the specificities of this body culture movements, with a proper rhythmic structure (reinforced by music), which are performed in pairs. This program should be tested in an enlarged sample, and in other learning contexts (e.g., schools, clubs), to test its applicability.

Keywords: Martial arts; combat sports; capoeira; children; motor learning; dyad.
\end{abstract}

\section{Los fundamentos básicos del aprendizaje de la capoeira: evaluación preliminar de un programa formativo}

\section{Resumen}

La capoeira es un duelo simulado, apoyado por el ritmo que marcan los instrumentistas con instrumentos musicales tradicionales; que evoluciona en una sincronía constante con el otro capoeirista. Hoy en día, la capoeira se transmite mediante procedimientos tradicionales, de acuerdo con la experiencia acumulada y las interpretaciones personales de cada Mestre de capoeira (maestro/entrenador de capoeira). El propósito de este estudio piloto fue realizar una evaluación preliminar de un programa para aprender las técnicas básicas, para los enseñantes de capoeira, respetando los valores culturales e históricos identitarios de la capoeira; aplicado a 15 niños de primer grado (Medad = $8.0 \pm 1.2$ años), pertenecientes a una organización no gubernamental, con roles sociales integradores, y a un club deportivo nacional, todos principiantes de capoeira; a lo largo de 30 sesiones ( 90 minutos cada una), durante tres meses. Los resultados mostraron que se produjo una mejora significativa en la calidad de la ejecución de todas las doce técnicas de capoeira seleccionadas, sin diferencias
Fundamentos básicos da aprendizagem da capoeira: avaliação preliminar de um programa formativo

\section{Resumo}

A capoeira é um duelo simulado, sustentado no ritmo de instrumentistas, tocado com instrumentos musicais tradicionais, e que evolui numa sincronia constante entre capoeiristas. Atualmente, a capoeira é transmitida por métodos tradicionais, de acordo com a experiência e interpretações pessoais do Mestre de capoeira. 0 objetivo deste estudo piloto foi apresentar uma avaliação preliminar de um programa de aprendizagem das técnicas básicas, para agentes de ensino de capoeira, respeitando os valores culturais e históricos da identidade da mesma. 0 programa foi aplicado a 15 crianças do $1^{\circ}$ ciclo do ensino básico (Midade $=8.0 \pm 1.2$ anos), todas inexperientes em capoeira; oriundas de uma organização não governamental, com papéis sociais integradores, e de um dos principais clubes desportivos nacionais. 0 programa compôs-se de 30 sessões (90 minutos cada sessão), durante 3 meses. Os resultados revelaram que houve melhoria significativa na qualidade de execução motora em todas as doze técnicas de capoeira selecionadas, sem

*E-mail: catela@esdrm.ipsantarem.pt 
significativas entre los géneros y el origen institucional de los participantes, lo que sostiene el potencial cultural y social de la capoeira. La práctica en dupla (díada), en la habilidad fundamental de la ginga, hizo posible la sincronización entre los niños desde el primer momento, en sintonía con una de las especificidades de los movimientos de la cultura corporal de la capoeira, con una estructura rítmica adecuada (reforzada por la música), que se desarrolla en parejas. Para evaluar su aplicabilidad, este programa debe probarse en una muestra más amplia y en otros contextos de aprendizaje (e.g., escuelas, clubes).

Palabras clave: Artes marciales; deportes de combate; capoeira; niños; aprendizaje motor; díada. diferença significativa entre géneros ou entre origem institucional; sustentando, assim, o potencial cultural e social da capoeira. A prática na dupla da habilidade essencial ginga, em díade, originou uma sincronização quase imediata entre as crianças; resultado que está em consonância com uma das especificidades desta cultura corporal: a sincronia entre capoeiristas da dupla, sustentada pela estrutura rítmica de cada técnica e reforçada pelas músicas. Este programa carece de testagem numa amostra mais alargada e em outros contextos de aprendizagem (e.g., escolas, clubes).

Palavras-chave: Artes marciais; desportos de combate; capoeira; crianças; aprendizagem motora; díade.

\section{Introduction}

Capoeira is a simulated duel supported by the rhythmic of instrumentalists, with traditional musical instruments. The temporal structure of the songs gives the basic rhythmic structure of the specific motor abilities of capoeira. So, capoeira duels evolve in a process of constant synchrony with the other capoeirista (capoeira practitioner) and, also with the music. Nowadays, capoeira is passed on by traditional processes, based on experience and personal interpretations of the Mestre de capoeira (capoeira master/coach), each one developing an individual philosophy and methodology. In Portugal and in Brazil (where capoeira comes from), there is no formal process and specific training of these professionals, and subjective criteria determines status qualification (Heine, Carbinatto, \& Nunomura, 2009). Sport education format, based on motor learning and motor control theories and theoretical models, ensures better results than traditional formats (e.g., Browne, Carlson, \& Hastie, 2004).

In the $5^{\text {th }}$ International Martial Arts and Combat Sports Scientific Society Conference, Barros, Branco, and Catela (2016) proposed a project to build and test a guideline program for learning the basic techniques, for capoeira teaching agents, with respect to the cultural and historical values of capoeira' identity; particularly for children, because this period of development is considered the critical one for motor skills and coordinative abilities' acquisition (Mitra \& Mogos, 1990), as well as for the structuring of modes of social interaction (Ré, 2011). Some studies have found that capoeira can contribute to the motor and psychomotor development of children with typical and atypical development, improving coordinative capacities, even in children with Down Syndrome (Andrade, 2012; Brito, 2008, 2014).

Ginga is assumed to be a capoeira' lead-up specific motor ability (e.g., Brennecke, Amadio, \& Serrão, 2005), probably because of its basic movement and rhythmical structure; that with some other techniques are assumed to be adequate to initial capoeira learning, such as negativa fechada and martelo (Hammer), whereas other specific abilities require more experience, like parafuso and armada pulada (Brennecke, Matsumoto, Machado, Gama, \& Serrão, 1998). However, to our knowledge, we have not found any study validating a specific learning program for school aged children, except for the proposed program of Souza and Oliveira (2008) for first grade school children, which was divided as follows: basics, defensives, offensives (direct and rotatory), acrobatics, and sliders; as well as with an introduction of the instruments and essential capoeira rhythms. Additional dispersed technical information was also found in specialized publications as Pensar a Prática (2009) and numerous videos, available at the library of the Portuguese Federation of Capoeira.

Therefore, the purpose of this pilot study was to assess the impact of a capoeira program in children, novice to this sport. The hypotheses of this study are:

i) Children are able to learn twelve selected essential techniques; and,

ii) Typical capoeira dyad practice affords children synchronization. 


\section{Methods}

\subsection{Sample}

The sample consisted of 15 children aged between 6 and $10\left(M_{\text {age }}=8.0 \pm 1.2 ; 6\right.$ years old $-n$ $=2 ; 7$ years old $-n=3 ; 8$ years old- $n=4 ; 9$ years old- $n=5 ; 10$ years old- $n=1$ ), 7 girls. Part of the children $(n=6)$ came from a non-governmental organization, with integrative social roles, that works with children from families with low socioeconomic status and minority ethnicities, in a pro bono modality; and, from a national sports club $(n=9)$, for the first time inscribed in the capoeira club team. Children were beginners in capoeira, with no previous experience in this sport. Informed consent from the parents and assent of the children was obtained. The principles of the Helsinki Treaty for human studies were respected.

\subsection{Variables}

For the first hypothesis, the independent variable is the program, and for the second one it is dyad (roda) condition. The dependent variable is the frequency of occurrence of critical components for each selected capoeira technique. Age, gender and origin are control variables.

\subsection{Program}

Respecting capoeira cultural identity and rituals (Vieira \& Assunção, 1998), such as the rhythmic structure and the participants' spatial organization and the roles (Alleoni, 2010), a playful dimension was ensured in the dialogue among the various actors involved in the roda (Heine, Carbinatto, \& Nunomura, 2009). Roda is a way of doing capoeira in a group, where the practitioners are arranged in a circle, in which the typical instruments are played and where the fighting takes place. So, the opportunity to deliberate practice and play was preserved, especially with the possibility of movement' free exploration (Reis, 1997). The movements were synchronized with specific rhythms (Heine, Carbinatto, \& Nunomura, 2009). The learning of specific motor skills was based on the lead-up technique ginga (Netto, 2007). The proposed content was initially based on the systematization of Souza and Oliveira (2008), from whom a set of basic contents were selected, defined, and organized; divided into two dimensions: i) the covering of cultural and historical roots; such as instruments, music and rituals; and ii) the acquisition of specific motor skills, divided in the following categories: specialized, transitional, and defensive movements (Table 1).

Table 1. Dimensions and elements worked with first grade children in the program for capoeira initiation.

\begin{tabular}{|c|c|}
\hline Cultural Dimension & Motor Dimension \\
\hline $\begin{array}{l}\text { - History: Legalization as regional fight "Capoeira Regional } \\
\text { Baiana", at the Physical Culture Centre of Salvador da Bahia } \\
\text { (1937), and at the Sport Centre of Capoeira Angola (1940), } \\
\text { also at Salvador da Bahia. Recognized as a national sport of } \\
\text { Brazil (1974), and recognized as common heritage by } \\
\text { UNESCO (2014). } \\
\text { - Instruments: Berimbau (three), Pandeiro, Reco-Reco, Agogô, } \\
\text { Atabaque (Capoeira Regional: Berimbau and two Pandeiros). } \\
\text { - Rhythms, Songs and Rituals: In the Capoeira Angola, the roda } \\
\text { starts with a Ladainha, quatrains normally sung by the Mestre } \\
\text { and older capoeiristas, followed by Louvações entra os } \\
\text { Corridos. In the Capoeira Regional, the roda starts with a } \\
\text { quatrain sung by the Mestre Charangueiro, followed by } \\
\text { Louvações entra os Corridos. In both, the roda starts with the } \\
\text { term "Volta do Mundo". }\end{array}$ & $\begin{array}{l}\text { A) Specialized abilities: } \\
\text { - Meia Lua de Frente } \\
\text { - Queixada } \\
\text { - Martelo } \\
\text { - Godeme } \\
\text { - Arpão de Giro } \\
\text { - Meia Lua de Compasso } \\
\text { - Armada } \\
\text { - Bênção } \\
\text { - Negativas } \\
\text { B) Transitional and Defensive movements: } \\
\text { - Ginga } \\
\text { - Cocorinha } \\
\text { - Aú }\end{array}$ \\
\hline
\end{tabular}

The program was implemented by a male mestre de capoeira, that founded a capoeira school in Lisbon, who holds a bachelor's in physical education, has a Master in Sports Sciences, and, was responsible for the development of education programs at the Portuguese Capoeira Federation; he obtained the first degree of mestre de capoeira in 1997 and the fourth degree in 2007, by the International Federation of Capoeira. 
The program was composed of 30 sessions (cf., Brito, 2014), over three months, with the mean duration of 90 minutes each session. The number of sessions was not previously defined; the criterion was to observe children's motor and socio-motor (roda) evolution, based on anecdotal registrations, until a perception of general acquisition was achieved, in order to have a notion of how many sessions would be needed for children to acquire the contents of the defined program. All sessions were run with all children, and intervention was the same, whichever age, gender or origin.

\subsection{Design}

A one-group pretest-posttest study was implemented. Evaluation was conducted at two levels: i) quality of twelve selected basic specialized capoeira abilities; and, ii) Ginga synchronization among capoeira pair of players, in the roda. The qualitative evaluation of the abilities was of nominal dichotomous checklist, with facial validation by a panel of experts in motor development, motor control, biomechanics, and a mestre de capoeira (e.g., Brennecke, Amadio \& Serrão, 2005). Critical components included static postures and dynamic actions, from the beginning until the end of the cycle (when continuous movements) or until the end of the movement (when discrete movements); and for symmetrical techniques, bilateral actions were analyzed. As an example of the checklist used, with critical components for the included capoeira techniques in the program, ginga critical components were the following, from the beginning to the end of the movement: i) Place an advanced lower limb and another recessed, in the anteroposterior plane, slightly flexed and distanced; ii) Simultaneously, place contralateral upper limb bent at the elbow above the level of the shoulders, in the horizontal plane; iii) maintaining limbs bent, drag lower limb receding forward, placing it next to an advanced lower limb, at shoulder width; iv) Dragging back lower limb initially advanced to position symmetrical to the initial of these limbs; v) Simultaneously, recede downwardly elevated upper limb and elevate lower recessed upper limb in symmetrical movement; vi) Do the same action in the opposite direction. A document (Portuguese version) with all techniques and respective critical components used, is available in Appendix 1.

\subsection{Instruments}

For quantitative analysis of the essential motor ability ginga, to construct the biomechanical model, a reflective marker was placed on the head. A Sony FDR_AXP33 digital 4K Video Recorder and two Sony DV-VCR cameras were used for image collection at a sampling frequency of $25 \mathrm{~Hz}$. The videos were cut applying VirtualDub software (virtualdub.org). The video calibration and analysis were done using SkillSpector software (video4coach). The virtual space was calibrated using eight calibration points, with specific coordinates $(x, y, z)$. Once the markers were identified and digitized in all frames, the reconstruction of the trajectory was done using the Direct Linear Transformation-DLT algorithm (Abdel-Aziz, Karara, \& Hauck, 2015). These trajectories were smoothed using a low-pass digital filter with a cut-off frequency of $5 \mathrm{~Hz}$ (Winter, 2009). The reconstruction of the virtual segments considering the coordinates of the points was done using MatLab software (Matworks, Inc).

\subsection{Statistical treatment}

Statistical Package for the Social Sciences (SPSS), v.23.0, was used. For normal distribution data, the Shapiro-Wilk test was used; however, due to sample size, non-parametric tests were used, with supplemental probabilistic interpretation (Monte Carlo), supplemental quantification of the effectiveness of the intervention (effect size $r$, and effect size eta-squared $\eta^{2}$ ), and supplemental rank-biserial correlation between pre and post data (Wilcoxon rank-biserial correlation coefficient $r r b$, and Mann-Whitney Glass rank-biserial $r r b$ ). For the association between variables, the Spearman correlation coefficient ( $r h o$ ) was used. The Wilcoxon test $(Z)$ was used for within-subject comparisons. The Kruskal-Wallis test $(H)$ and the Mann-Whitney U test $(Z)$ were used for between subjects' comparisons, for age comparisons, and for gender, origin and pre -post comparisons (Z). The significant level was set at .05, two-sided. Intra rater agreement was estimated with Cohen' Kappa (Kottner, Audigé, Brorson, Donner, Gajewski, Hróbjartsson et al., 2011) 


\section{Results}

\subsection{Intra rater agreement}

For intra rater agreement, three participants with different levels of performance were filmed, and observed by a mestre of capoeira, who used our checklists for critical components, in two observations, separated by one week, of the following techniques: ginga, cocorinha, armada, and meia lua de compasso; as they are considered lead-up techniques. Agreement ranged from moderate (meia lua de compasso) to perfect (cocorinha), with agreements always equal or above $80 \%$ (Table 2). The evaluation of all participants, in both moments (Pre-Test, Post-Test), was done by this same observer.

Table 2. Estimation of percent of agreement (\%), Cohen' Kappa, standard error of Cohen' Kappa $(S E)$, interval of confidence $(C I)$ and strength, by technique analysed.

\begin{tabular}{lccccc}
\hline \multicolumn{1}{c}{ Technique } & \% & Kappa & \multicolumn{1}{c}{$\boldsymbol{E}$} & $\mathbf{9 5 \%} \boldsymbol{C I}$ & Strength \\
\hline Ginga & 94.44 & .889 & .076 & .74 to 1.00 & Very Good \\
Cocorinha & 100 & 1 & .000 & 1.00 & Perfect \\
Meia lua de compasso & 95.45 & .909 & .051 & .809 to 1.00 & Very Good \\
Armada & 80.00 & .596 & .100 & .399 to .793 & Moderate \\
\hline
\end{tabular}

\subsection{Program analysis}

In order to verify if age, gender or origin (social institution, club) had an influence on results, comparisons were made. For the sum of the achieved critical components of the twelve techniques, no significant difference was found between ages, between origins and between genders, at the beginning (Pre-Test) and at the end (Post-Test) of the program implementation (Table 3). When comparing motor performance at the beginning and at the end of the program, there was a significant improvement in the quality of execution in all capoeira techniques analysed (Table 4).

Table 3. Comparison among beginning (Pre-Test) and end (Post Test) of the program, for age (Kruskal-Wallis- $H$ ), gender, and origin (Mann-Whitney- Z), for the set of capoeira's abilities practiced, and effect size $(r)$ and estimation of Mann-Whitney Glass rank-biserial $(r r b)$ estimations for gender and origin; and, effect size eta-squared $\left(\eta^{2}\right)$ estimation for age.

\begin{tabular}{|c|c|c|c|c|c|c|}
\hline \multirow{2}{*}{ Variable } & \multicolumn{3}{|c|}{ Pre-Test } & \multicolumn{3}{|c|}{ Post Test } \\
\hline & & $\eta^{2} / r$ & $r r b$ & & $\eta^{2} / r$ & $R r b$ \\
\hline Age $H(4)$ & $3.530, \mathrm{~ns}$ & -.05 & - & $4.500, \mathrm{~ns}$ & .05 & - \\
\hline Gender Z(15) & $-.927, \mathrm{~ns}$ & -.24 & .29 & $-.753, \mathrm{~ns}$ & -.19 & -.23 \\
\hline Origin $Z(15)$ & $-1.417, \mathrm{~ns}$ & -.37 & -.44 & $-1.298, \mathrm{~ns}$ & -.34 & -.41 \\
\hline
\end{tabular}

Table 4. Comparison $(Z)$ among Pre-Test and Post Test evaluations, and effect size $(r)$ and Wilcoxon rank-biserial correlation coefficient $(r r b)$ estimations, by technique.

\begin{tabular}{lcccl}
\hline Technique & $\boldsymbol{Z}$ & $\boldsymbol{p}$ & $\boldsymbol{r}$ & $\boldsymbol{r} \boldsymbol{R} \boldsymbol{r} \boldsymbol{b}$ \\
\hline Ginga & -3.449 & .001 & -.89 & -.97 \\
Cocorinha & -3.437 & .001 & -.89 & -.97 \\
Aú & -2.701 & .007 & -.70 & -.96 \\
Meia Lua de Frente (Half-Moon Front) & -3.315 & .001 & -.86 & -.97 \\
Queixada & -3.309 & .001 & -.84 & -.97 \\
Martelo (Hammer) & -3.433 & .001 & -.89 & -.97 \\
Godeme & -3.477 & .001 & -.90 & -.97 \\
Arpaú & -3.482 & .0001 & -.90 & -.97 \\
Meia Lua de Compasso (Half-Moon Compass) & -3.000 & .003 & -.77 & -.97 \\
Armada & -3.308 & .001 & -.85 & -.97 \\
Bênção (Blessing) & -3.241 & .001 & -.83 & -.97 \\
Negativa & -3.192 & .001 & -.82 & -.97 \\
\hline
\end{tabular}


As can be seen from the probability obtained (Table 2), the aú and the half moon compass techniques were probably the least accessible ones to the whole sample. However, in the set of techniques analysed and for the sample, success rate was high. Additionally, there was no significant association among Pre-Test and Post-Test results ( $r$ o $(15)=.251, p=.368$ ); meaning that children revealed distinct motor performance in these evaluation moments.

In the ginga technique the most common mistakes were incorrect foot positioning and excessive lower limb flexion. In all children, the difficulty of vertical maintenance of the trunk is evident, when this is essential (e.g., hammer, half-moon front, and half-moon compass). The orientation of the face or the conservation of this orientation to the body of the companion was the most common mistake, mainly in the techniques godeme, hammer and half-moon compass. Another very common error was the lack of rotation of the foot of the support member when this is required (e.g., queixada). In the armada technique the loss of targeting of the coup, was the most frequent failure, perhaps due to interruption of visual contact with the partner. In the execution of the aú, the children showed difficulty in not projecting alternately the lower limbs and in the exchange of hands' support. In the bênção, the foot did not rise above the horizontal plane of the hip, it lacked total extension of the knee of the projected lower limb, and there was no orientation of the sole of the foot to the companion body. In the negativa technique the most common difficulty was that of the foot fitting in the companion's heel.

Although not the object of this qualitative analysis, our anecdotal records showed that the practice in pairs (necessary to gauge the adequacy of the orientation of body segments, the form and areas of contact with the companion) revealed some children's fragilities, mainly associated with the synchronization with the couple, e.g., in the cocorinha and negativa techniques the movements were either executed too soon or too late.

\subsection{Ginga dyad analysis}

In the two moments of the program, for the individual condition, there is a lower dispersion of values and a greater amplitude of displacement than in the dyad condition; this pattern is consistent in statistical central tendency parameters (Table 5, Figure 1).

Table 5. Descriptive statistics of the relative position of the head in space, at the beginning (Pre-Test) and at the end (Post Test) of the program, for individual and dyad conditions, in ginga fundamental motor ability.

\begin{tabular}{llc}
\hline Moment \& Condition & $\boldsymbol{M} \pm \boldsymbol{S D}$ & Mdn (Interquartile) \\
\hline Individual Pre Test & $1.99 \pm .52$ & $1.95(.93)$ \\
Individual Post Test & $1.28 \pm .76$ & $1.07(.81)$ \\
Dyad Pre Test & $1.08 \pm .84$ & $.78(1.46)$ \\
Dyad Post Test & $1.10 \pm .79$ & $.93(1.33)$ \\
\hline
\end{tabular}

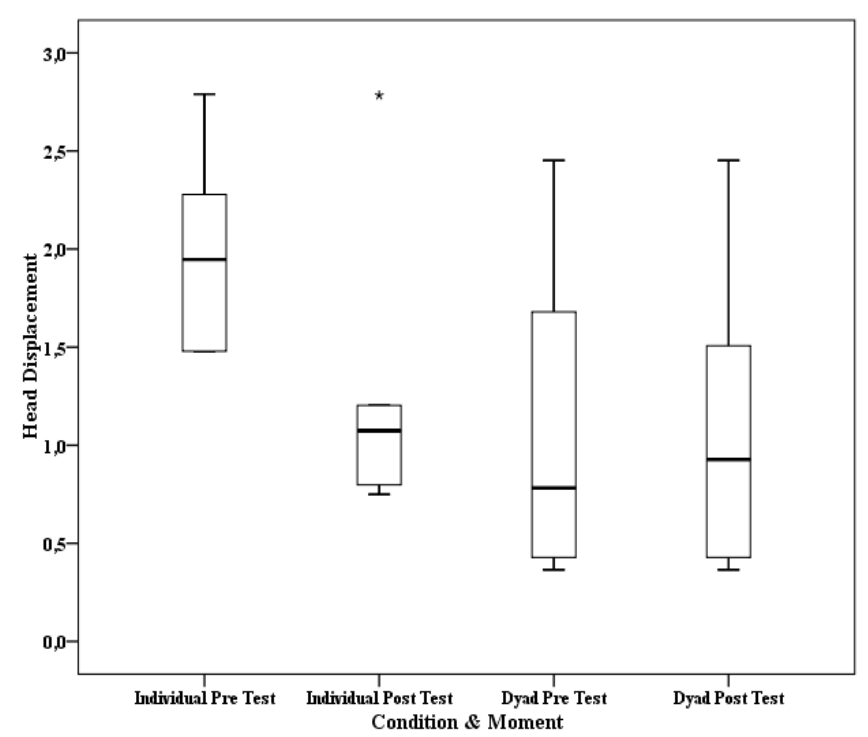

Figure 1. Box plot of the relative position of the head in space, at the beginning (Pre-Test) and at the end (Post Test) of the program, for individual and dyad conditions, in ginga fundamental motor ability. 
Between conditions, this difference in the motor behavior is significant at the initial moment (Pre-Test), which is supported by strong effect size and rank-biserial correlation coefficient $(z=-2.510, p<.05, r=.67, r r b=-.60)$. However, it disappears at the final moment (Post Test) of the program $(z=-.105, p=.917, r=-.31, r r b=-.75)$.

In addition, when the variability of the head displacement in space (standard deviation) was analysed, it was observed that, from the initial moment to the final moment of the program, for the individual condition, the spatial variability decreases, indicating a more linear movement; as in the dyad condition this variability increases, probably indicating an attempt to align the trajectory with the pair (Table 6, Figure 2). These results reinforce those obtained in the amplitude of the relative position of the head in space. In particular, it should be noted that in the dyad condition, at the initial and final moments of the program, the pattern of distribution of values is very similar, probably expressing a combination of individual behavior and the constraint of performing the movement with another child.

Table 6. Descriptive statistics concerning the standard deviation of the relative position of the head in space, at the beginning (Pre-Test) and at the end (Post Test) of the program, for individual and dyad conditions, in ginga fundamental motor ability.

\begin{tabular}{lcc}
\hline Moment \& Condition & $\boldsymbol{M}$ & $\boldsymbol{M d n}$ \\
\hline Individual Pre Test & .38 & .36 \\
Individual Post Test & .24 & .26 \\
Dyad Pre Test & .21 & .14 \\
Dyad Post Test & .23 & .17 \\
\hline
\end{tabular}

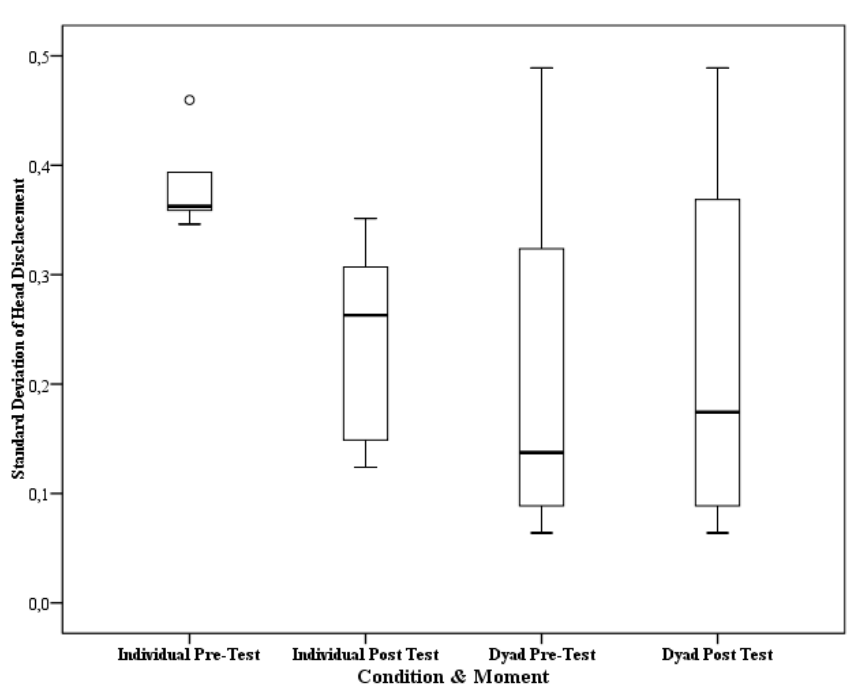

Figure 2. Box plot of the standard deviation of the head displacement in space, at the beginning (Pre-Test) and at the end (Post Test) of the program, for individual and dyad conditions, in ginga fundamental motor ability.

This difference in the pattern of behavior between the individual and dyad conditions is significant at the initial moment of the program, which is sustained by a moderate effect size and by a strong rank-biserial correlation coefficient $(z=-2.432, p<.05, r=0.50, r r b=-.85)$; which disappears at the final moment of the program $(z=-.105, p=.917, r=.0, r r b=-.11)$. However, it significantly decreases in the individual condition from the initial moment to the end of the program $(z=-2.201, p<.05, r=1.0, r r b=-1.0)$, although in the paired condition there was no significant difference between the two moments $(z=-.738, p=.461, r=.30, r r b=-.33)$. This may mean that initially each child managed the variability of their movement in space in a very specific way, due to their intrinsic constraints, but when faced with the constraint of the "peer" task, and, also, because of the practice experience, his/her spatial variability changed, during ginga's execution. These results reinforce the hypothesis that the intervention has led to an evolution in the quality of the technical execution of ginga, a fact that was already confirmed in the qualitative analysis presented previously; as the hypothesis that dyad practice, which represents one of the essential aspects of capoeira (the duplas), constrains, from the outset, an (unintentional) need for 
synchronization with the other. It should be noted that for initial data collection in dyad condition, the children who had never done capoeira, were only told to look at their pair.

\section{Discussion}

The purpose of this pilot study was to assess the impact of a capoeira program in children, novice to this sport. The main purpose of the study was achieved, the implementation of the program allowed capoeira' novice children to learn twelve essential techniques. It was hypothesized that children were able to learn the selected essential techniques. Results obtained sustain this hypothesis, the selected techniques and the roda practice, fit this age range, benefiting equally children of different social origins and of both genders. In children of this age, inexperienced in capoeira, thirty sessions with a specialist were enough for a significant evolution in twelve capoeira selected techniques. At the moment, it is unknown whether the program can be implemented by a non-specialist in capoeira, or in other contexts, like school.

One of the followed criteria for the selection of the techniques was that they are considered as lead-up ones in capoeira, e.g., in the knocks the learning of the half moon forward predates all other standing knocks, such as the queixada, which is the same technique as half moon front but in the opposite direction. Similarly, in the defenses, the cocorinha is fundamental for all the falls and defenses; because all of them execute the positioning as a squatting response (e.g., negative). In a certain way, the learning of these lead-up techniques, work as a partial practice for the other techniques, which can be classified as serial motor skills, that is, composed of separately learned subunits, before being combined into a single motor action. The execution of some techniques will also result in new ones, e.g., hammer and armada gives rise to parafuso; half moon front and armada combined result in a half moon armada, and its synergy can increase the speed of the latter. From the transitional and defensive techniques, we selected the ginga, cororinha, and aú, because they allow the attack-defense and defense-attack transitions. In the essential combinations of capoeira at least one of these techniques is always present.

Although it was not the purpose of this study, but because of its identity importance, the cultural component was present in all sessions, covering historical, instrumental, musical and ritualized aspects of capoeira. In this way, all sessions were accompanied by songs, and the capoeiristas practice at the roda, in the end of each session.

It was also hypothesized that typical capoeira dyad practice would afford children synchronization. Since capoeira is essentially a dialogical and a non-contact confrontation between at least two persons, as it is distinguished from other combat practices, it was fundamental to analyze the effect of the program on the interaction between pairs of children, simulating the dupla (dyad condition). Probably, the most surprising result is that even though at the beginning of the program, when the children were asked to look at their pair while they both tried to perform ginga (which they had first tried out for), their pattern of behavior indicates an immediate tendency to synchronize spatially, and distinctly from when they were asked to perform the skill alone. These results support the hypothesis that the dyad condition provides synchronization among the children, since there is a greater dispersion of the values, in both moments, probably representing the specific pattern of each pair; also characterized by a mean reduction of the displacement of the head in the space, probably resulting from the attempt of synchronization between the two children, because the smaller the space covered the less the possibility of an asynchrony between the two participants in the roda. In addition, at the end of the program, when they were again observed in the ginga, not only did the children show no difference in space displacement in the dyad condition (dupla), but they also evolved individually compared to the beginning of the program.

These results are also in line with several theoretical models in the area of motor behavior. They are consistent with the hypothesis of mirror neurons, in the sense that they are considered as sustainers of social interaction (Sommerville \& Decety, 2006). Our results are consistent with the hypothesis of dyad influence in motor learning (Wulf, Shea, \& Lewthwaite, 2010), because children automatically change their pattern of movement in space when in peer condition. They are also consistent with the hypothesis of sensorimotor synchronization (Repp \& Su, 2013), since it seems 
that children are unaware of the tendency to synchronize their movements in space when in dyad condition; note, for example, the patterns of standard deviation of head displacements in space for conditions and moments.

This program should be tested in an enlarged sample, and in other learning contexts, like physical education teacher training (e.g., Santos, \& Palhares, 2010), to test its applicability. Additionally, more than one observer, including an outside observer, should be used to determine intra rater and inter rater agreement, in order to avoid potential internal validity threats, like observer-expectancy effect; and in order to better test reliability of the checklists of critical components used.

\section{Conclusion}

The program, as conceived and implemented, efficiently benefited gender and social origin in the learning of capoeira's essential techniques. These results reinforce the cultural and social affordances that it possesses (cf. Heine, Carbinatto, \& Nunomura, 2009). The absence of difference in motor performance between girls and boys is important, since gender differences are known in studies on performance in fundamental motor skills (Brito, 2008, 2014).

The program, as conceived and implemented, provides qualitative motor learning of the twelve selected techniques, after thirty sessions with inexperienced children in capoeira; and results of this study support part of the program proposed by Souza and Oliveira (2008), for this age interval.

The practice in dupla simulation (dyad condition), in the fundamental ginga ability, provided synchronization among children from the first moment, in tune with one of the specificities of this body culture - movements with a proper rhythmic structure (reinforced by music), which are performed in pairs (Heine, Carbinatto \& Nunomura, 2009); that, traditionally, in the initial phase of learning are made in symmetry.

This program should be tested in an enlarged sample, to ensure its external validity. Additionally, the checklists of critical components used should be tested in a panel of observers, to determine intra rater and inter rater agreement, in order to avoid potential internal validity threats, like observer-expectancy effect; and in order to better test reliability of those checklists, namely, to be used as instruments of evaluation of practitioners' motor learning progress and critical errors in movement control.

It is suggested that this program be tested in a school context, with teachers with basic training in capoeira, and other learning contexts of capoeira, e.g., clubs, even with older children than of those of our sample, to test the eventual universality of the program designed.

\section{References}

Abdel-Aziz, Y. I., Karara, H. M., \& Hauck, M. (2015). Direct linear transformation from comparator coordinates into object space coordinates in close-range photogrammetry. Photogrammetric Engineering \& Remote Sensing, 81(2), 103-107. doi: 10.14358/PERS.81.2.103

Alleoni, B. N. (2010). A Manifestação Corporal Capoeira: Uma Cultura Nacional Brasileira. Revista Mackenzie de Educação Física e Esporte, 9(1), 24-31.

Andrade, A. C. (2012). Vivências e fundamentos de um Mestre de capoeira. São Paulo: Matrix.

Barros, N., Branco, M. A., \& Catela, D. (2016). The basic foundations of Capoeira learning from 5 to 10 years of age: implementation and evaluation of a formative project. Revista de Artes Marciales Asiáticas, 11(2s), 64-65. doi: 10.18002/rama.v11i2s.4174

Brennecke, A., Amadio, A. C., \& Serrão, J. C. (2005). Parâmetros dinâmicos de movimentos selecionados da Capoeira. Revista Portuguesa de Ciências do Desporto, 5(2), 153-159.

Brennecke, A., Matsumoto, J., Machado, R., Gama, W., \& Serrão, J. C. (1998). Análise bidimensional do deslocamento do centro de gravidade no "bico de papagaio" da capoeira. In Anais do V Congresso de Iniciação Científica e III Simpósio de Pós-Graduação (pp. 106-107). São Paulo: EEFEUSP. 
Brito, A. (2008). Capoeira, um contributo para a melhoria da coordenação motora em indivíduos com Síndrome de Down (Unpublished master dissertation). Universidade do Porto, Faculdade de Desporto. Porto, Portugal.

Brito, A. C. D. (2014). A Influência da Capoeira no Desenvolvimento Psicomotor de Crianças (Unpublished doctoral dissertation). Universidade Federal do Ceará, Faculdade de Educação, Programa de Pós-Graduação em Educação Brasileira. Fortaleza, Brasil.

Browne, T. B., Carlson, T. B., \& Hastie, P. A. (2004). A comparison of rugby seasons presented in traditional and sport education formats. European Physical Education Review, 10(2), 199-214. doi: $10.1177 / 1356336 X 04044071$

Heine, V., Carbinatto, M. V., \& Nunomura, M. (2009). Estilos de ensino e a iniciação da capoeira para crianças de 7 a 10 anos de idade. Pensar a Prática, 12(1), 1-12.

Kottner, J., Audige, L., Brorson, S., Donner, A., Gajewski, B. J., Hrobjartsson, A., . . Streiner, D. L. (2011). Guidelines for Reporting Reliability and Agreement Studies (GRRAS) were proposed. Journal of Clinical Epidemiology, 64(1), 96-106. doi: 10.1016/j.jclinepi.2010.03.002

Mitra, G., \& Mogos, A. (1990). O Desenvolvimento das Qualidades Motoras no Jovem Atleta. Lisboa: Livros Horizonte.

Netto, N. S. P. A. (2007). A capoeira no município de campo largo, estado do Paraná: uma experiência educacional a partir da abordagem crítico-superadora em educação física escolar. In VII Congresso Nacional de Educação - EDUCERE. (Anais) (pp. 2294-2306). Pontifícia Universidade Católica do Paraná - PUC-PR. Curitiba: 2007.

Ré, A. H. N. (2011). Crescimento, maturação e desenvolvimento na infância e adolescência: Implicações para o esporte. Motricidade, 7(3), 55-67.

Reis, L. V. S. (1997). $O$ mundo de pernas para o ar: A Capoeira no Brasil. São Paulo, SP: Brasil.

Repp, B. H., \& Su, Y. H. (2013). Sensorimotor synchronization: a review of recent research (20062012). Psychonomic bulletin \& review, 20(3), 403-452. doi: $10.3758 / \mathrm{s} 13423-012-0371-2$

Santos, G. D. O., \& Palhares, L. R. (2010). A Capoeira na formação docente de Educação Física. Pensar a Prática, 13(3).

Sommerville, J. A., \& Decety, J. (2006). Weaving the fabric of social interaction: Articulating developmental psychology and cognitive neuroscience in the domain of motor cognition. Psychonomic Bulletin \& Review, 13(2), 179-200. doi: 10.3758/BF03193831

Souza, S. A. R., \& Oliveira, A. A. B. (2008). Estruturação da capoeira como conteúdo da educação física no ensino fundamental e médio. Revista da Educação Física/UEM, 12(2), 43-50.

Vieira, L. R., \& Assunção, M. R. (1998). Mitos, controvérsias e fatos: construindo a história da capoeira. Revista de Estudos Afro-Asiáticos, 34, 81-121.

Winter, D. A. (2009). Kinematics. In Biomechanics and motor control of human movement (4th ed., pp. 34-38). Hoboken, N.J.: Wiley.

Wulf, G., Shea, C., \& Lewthwaite, R. (2010). Motor skill learning and performance: a review of influential factors. Medical education, 44(1), 75-84. doi: 10.1111/j.1365-2923.2009.03421.x

\section{Appendix 1. Checklist of critical components used for qualitative analysis of the movement, per technic included in the program (in Portuguese)}

\section{Ginga}

$\checkmark$ Colocar um membro inferior avançado e outro recuado, no plano anteroposterior, ligeiramente fletidos e afastados;

$\checkmark$ Simultaneamente, colocar membro superior contralateral fletido pelo cotovelo acima do nível dos ombros, no plano horizontal;

$\checkmark$ Mantendo flexão dos membros, arrastar membro inferior recuado para diante, colocando-o ao lado de membro inferior avançado, pelo menos à largura dos ombros; $\checkmark$ Arrastando recuar membro inferior inicialmente avançado para posição simétrica à inicial destes membros;

$\checkmark$ Simultaneamente, recuar para baixo membro superior elevado e elevar membro superior recuado e baixo, num movimento simétrico;

$\checkmark$ Efetuar mesma ação no sentido oposto.

Cocorinha

$\checkmark$ Durante flexão dos membros inferiores, pés paralelos totalmente apoiados no solo;

$\checkmark$ Durante flexão dos membros inferiores mantém cabeça vertical; 
$\checkmark$ Na posição de cócoras, apoia mão no solo com supinação do antebraço (dedos virados para fora);

$\checkmark$ Mão de apoio fica recuada, formando um triângulo escaleno com os pés;

$\checkmark$ Membro superior em frente ao rosto, flexionado pelo cotovelo;

$\checkmark$ Membro superior em frente do rosto acima do nível dos ombros.

\section{Martelo}

$\checkmark$ Partir da ginga,

$\checkmark$ Membro inferior recuado é tracionado a partir da anca;

$\checkmark$ Membro inferior é tracionado fletido pelo joelho;

$\checkmark$ Membro inferior tracionado faz trajetória acima do plano horizontal do joelho do membro inferior apoiado no solo;

$\checkmark$ Durante traçam, o tronco não baixa mais que plano horizontal de membro inferior tracionado;

$\checkmark$ Joelho de membro inferior tracionado é orientado para corpo do companheiro;

$\checkmark$ Pé de (e) membro inferior de apoio faz rotação supinada;

$\checkmark$ Perna de membro inferior tracionado é estendida, com orientação de dorso do pé para corpo de companheiro;

$\checkmark$ Retorno de membro inferior tracionado à posição inicial.

Bênção

$\checkmark$ Partir da ginga;

$\checkmark$ Elevar o membro inferior flexionado pelo joelho, com dorsiflexão do pé;

$\checkmark$ Extensão do membro inferior com orientação do pé em direção ao companheiro (golpear);

$\checkmark$ Movimento do golpear linear;

$\checkmark$ Movimento de golpear rápido;

$\checkmark$ Atingir companheiro com a planta do pé.

Aú

$\checkmark$ No plano frontal, inclinar lateralmente tronco em direção ao chão;

$\checkmark$ Mantendo esse plano, apoiar sucessivamente as duas mãos no solo;

$\checkmark$ Lançar membro interior recuado para cima e para a frente;

$\checkmark$ Estender membro inferior avançado para cima;

$\checkmark$ Com os membros inferiores descrever semicírculo;

$\checkmark$ Elevar tronco e cabeça, ao apoiar sucessivamente os pés no solo.

\section{Godeme}

$\checkmark$ Partir da Ginga;

$\checkmark$ Elevar membro superior flexionado pelo cotovelo e direcionado para cabeça de companheiro;

$\checkmark$ Fechar a mão com supinação do antebraço (dorso da mão orientado para cabeça de companheiro);

$\checkmark$ Estender o antebraço em direção a lado da cabeça do companheiro.

\section{Arpão de Giro}

$\checkmark$ Partir da ginga;

$\checkmark$ Avançar pé recuado, girando 180 graus sobre eixo longitudinal e mantendo rosto orientado para companheiro;

$\checkmark$ Termina rotação de costas para companheiro;

$\checkmark$ Durante rotação longitudinal mantem sempre pés em contacto com o solo;

$\checkmark$ Continuação da rotação da cabeça no sentido do movimento, orientando rosto para companheiro;

$\checkmark$ Membro superior é elevado em extensão acima de plano horizontal do ombro do membro superior de ataque

$\checkmark$ Membro superior elevado é projetado no sentido da rotação longitudinal inicialmente produzida, em direção a corpo de companheiro;

$\checkmark$ Mão de membro superior elevado e rodado é mantido em extensão, apresentando parte posterior da mão;

$\checkmark$ Conclui rotação longitudinal, ficando de frente para companheiro;

$\checkmark$ Durante toda a rotação no eixo longitudinal, mantem tronco e cabeça alinhados com este;

$\checkmark$ Executa para ambos os lados.

\section{Armada}

$\checkmark$ Partir da ginga;

$\checkmark$ Avançar pé recuado, girando 180 graus sobre eixo longitudinal e mantendo rosto orientado para companheiro;

$\checkmark$ Termina rotação de costas para companheiro;

$\checkmark$ Durante rotação longitudinal mantem sempre pés em contacto com o solo;

$\checkmark$-Continuação da rotação da cabeça no sentido do movimento, orientando rosto para companheiro;

$\checkmark$ Membro inferior inicialmente de apoio é elevado em extensão acima de plano horizontal do joelho do membro inferior de apoio

$\checkmark$ Membro inferior elevado é projetado no sentido da rotação longitudinal inicialmente produzida, em direção a corpo de companheiro;

$\checkmark$ Pé de membro inferior elevado e rodado é mantido em dorsiflexão, apresentando bordo externo companheiro;

$\checkmark$ Conclui rotação longitudinal, ficando de frente para companheiro;

$\checkmark$ Durante toda a rotação no eixo longitudinal, mantem tronco e cabeça alinhados com este;

$\checkmark$ Executa para ambos os lados.

Meia-Lua de Compasso

$\checkmark$ Partir da Ginga;

$\checkmark$ Flete tronco entre as coxas;

$\checkmark$ Apoia mãos no solo intercetando plano frontal dos pés (uma das mãos está recuada em relação a este plano);

$\checkmark$ Apoia mãos sensivelmente à largura dos ombros;

$\checkmark$ Apoia mãos com antebraços em supinação (dedos virados para as extremidades da semirreta que formam); 
$\checkmark$ Projeção do membro inferior recuado (da Ginga) acima do plano horizontal da anca do companheiro;

$\checkmark$ Projeção semicircular do membro inferior é acompanhada de rotação em pronação de membro inferior de apoio;

$\checkmark$ Fase descendente de membro inferior projetado é acompanhada de elevação do trem superior;

$\checkmark$ Ao apoiar pé de membro inferior projetado assume posição base da Ginga.

Meia-Lua de Frente

$\checkmark$ Partir da ginga;

$\checkmark$ Durante projeção de membro inferior recuado manter trem superior vertical;

$\checkmark$ Membro inferior projetado descreve semicírculo acima de plano horizontal do joelho;

$\checkmark$ golpe é realizado com o bordo interno do pé;

$\checkmark \quad 0$ pé do golpe está em dorsiflexão;

$\checkmark$ Durante o golpe o pé do membro inferior de apoio realiza uma rotação em supinação;

$\checkmark$ Ao apoiar pé de membro inferior projetado assume posição base da Ginga.

\section{Negativa}

$\checkmark$ Partir da ginga;

$\checkmark$ Durante flexão dos membros inferiores mantem rosto orientado para companheiro;

$\checkmark$ Durante flexão dos membros inferiores mantem rosto protegido por membro superior avançado;

$\checkmark$ Membro inferior recuado é projetado para a frente completamento em extensão; $\checkmark$ Pé de membro inferior projetado encontra-se em dorsiflexão;

$\checkmark$ Durante projeção do membro inferior membros superiores estão fletidos de modo a tórax tocar no solo

$\checkmark$ Pé do membro inferior projetado é orientado para calcanhar do companheiro;

$\checkmark$ Durante retorno de membro inferior projetado, mantem rosto orientado para companheiro;

$\checkmark$ Durante retorno de membro inferior projetado, reposiciona antebraço de membro superior avançado em frente de rosto;

$\checkmark$ Retorna à posição de ginga.

\section{Queixada}

$\checkmark$ Partir da ginga;

$\checkmark$ Durante todo o movimento mantem rosto orientado para companheiro; $\mathrm{Na}$ deslocação do membro inferior recuado mantem pé em contacto com o solo; Durante a projeção de membro inferior (deslocado) mantem trem superior vertical;

$\checkmark$ Executa movimento semicircular de membro inferior projetado;

$\checkmark$ o calcanhar do membro inferior projetado desloca-se acima do plano horizontal do joelho do membro inferior apoiado no solo;

$\checkmark$ Durante projeção o membro inferior, o membro inferior apoiado no solo realiza rotação de ajustamento em pronação;

$\checkmark$ Retorna à posição de ginga.

\section{Author's biographical data}

Nelson Barros (Portugal). MSc in Sport Sciences. He is the Chairman of the Portuguese Federation of Capoeira. He is the coordinator for the development of education programs at the Portuguese Federation of Capoeira. Since 2007, he has the $4^{\text {th }}$ Degree Master of Capoeira, certified by the International Federation of Capoeira. He is Head of the Research Unit of Pro-Capoeira, in the National Association of Capoeira Coaches; Member of the European Capoeira Union; Co-ordinator of Capoeira coaches' formation for the National Training Program for Coaches; and, is Mestre de Capoeira at the Sporting Clube de Portugal. E-mail: nelson.ar.barros@gmail.com

Marco Branco (Portugal) is a lecturer on the Sport Sciences School of Rio Maior, Polytechnic Institute of Santarém, Portugal, in the areas of Biomechanics and Motor Control and Learning. PhD in Human Kinetics, specialization in Biomechanics. Researcher of the Biomechanics and Functional Morphology Laboratory, Interdisciplinary Centre for the Study of Human Performance (CIPER), Faculty of Human Kinetics, University of Lisbon, and member of the International Martial Arts and Combat Sports Scientific Society (IMACSSS). His research focuses are on biomechanics and motor behavior, focusing on special populations and sport performance. He has the 3rd Dan in Wado-Ryu Karate and is a certified coach by the Federation of Karate Portugal (FNKP). E-mail: marcobranco@esdrm.ipsantarem.pt

David Catela (Portugal). MSc in Motor Development; PhD in Human Motricity. Assistant Professor, Head of Department of Movement Sciences (Polytechnic Institute of Santarém). Researcher in Motor Development, Motor Learning and Motor Control. Head of Applied Psychology- Research Unity of the Polytechnic Institute of Santarém (UI-IPS). Quality of Life Research Centre (CIEQV) Member. E-mail: catela@esdrm.ipsantarem.pt 